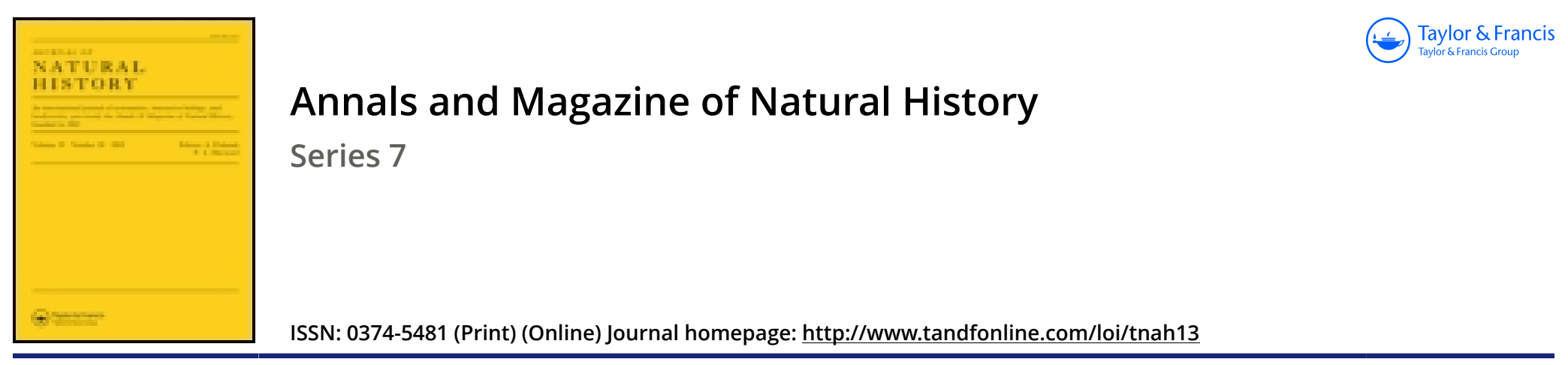

\title{
LIV.-Descriptions of some new species and varieties of Cataulus from the collection of the late Hugh Nevill, Esq.
}

\section{Hugh Fulton}

To cite this article: Hugh Fulton (1904) LIV.-Descriptions of some new species and varieties of Cataulus from the collection of the late Hugh Nevill, Esq. , Annals and Magazine of Natural History, 13:78, 452-453, DOI: 10.1080/00222930408562478

To link to this article: http://dx.doi.org/10.1080/00222930408562478

曲 Published online: 29 Sep 2009.

Submit your article to this journal $\pi$

Џll Article views: 2

Q View related articles $₫$ 
yellowish; lower parts yellowish, with a median series of olive-brown spots which, after the anterior fourth of the body, become confluent into a band.

Total length $355 \mathrm{~mm}$. ; tail 50 .

A single male specimen from Dinawa, Owen Stanley Range, Brit. New Guinea, altitude about 4000 feet; collected by Mr. A. E. Pratt.

LIV.-Descriptions of some new Species and Varieties of Cataulus from the Collection of the late Hagh Nevill, Esq. By Hugh Fulton.

\section{Cataulus rugosa, sp. $\mathrm{n}$.}

Shell very narrowly umbilicate, subfusiform, moderately solid, colour light yellowish brown, nucleus smooth, sculptured below with somewhat nodulous oblique strix, which give a malleated appearance to the shell; whorls $6 \frac{1}{2}$, moderately convex; basal carina moderately produced ; aperture circular, reddish brown within ; peristome yellowish, continuous ; basal canal semicircular, situate at centre of basal portion of the peristome.

Maj. diam. 5 ; alt. $11 \frac{1}{2} \mathrm{~mm}$.

Loc. Ceylon.

'This form is nearest to C. marginatus, but is much smaller, not so slender, and the suture is not margined.

\section{Cataulus Sykesi, sp. n.}

Shell narrowly umbilicate, subfusiform, solid, uniform light yellowish to uniform reddish-brown colour, arcuately striated, the striæ rather blunt and not very conspicuous; whorls nearly 7, slightly convex; basal carina prominent, with a conspicuous inner ridge; aperture subcircular, reddish brown within; peristome whitish, very much thickened but scarcely duplex, continuous; aperture of basal canal subcircular, situate slightly to the left of the centre of base of peristome.

Maj. diam. (yellow form) $6 \frac{1}{2}$; alt. $14 \frac{1}{2} \mathrm{~mm}$.

" " (reddish-brown form) $6 \frac{1}{2}$; alt. $14 \mathrm{~mm}$.

Loc. Ceylon.

$$
\text { (reddish-brown form) } 6 \frac{1}{2} \text {; alt. } 14 \mathrm{~min} \text {. }
$$

This form bears a general resemblance to C.duplicatus, Pf., but is smaller, has less whorls, and the suture of the earlier whorls is not margined as in that species. 
The penultimate whorl of duplicatus is wider in proportion to the last whorl than in Sykesi; the latter is also distinguished by its prominent inner basal ridge at the umbilical area.

Cataulus marginatus, $\mathrm{Pf}$., var. crenulata, nov.

Slightly broader than typical marginatus, less strongly malleated, and lacking the distinctly margined suture of that species; of a light reddish colour, and crenulated at and below the suture of the middle whorls, the antepenultimate showing it more distinctly.

Maj. diam. 6 ; alt. $15 \mathrm{~mm}$.

Loc. Ceylon.

\section{Cataulus Nevilli, Sykes, var. flaveolabris, nov.}

Lighter-coloured and with a yellow peristome, the latter being more on a plane with the spire than in typical Nevilli, which is generally somewhat produced forward at the basal portion.

IIaj. diam. 11 ; alt. $25 \mathrm{~mm}$.

Loc. Ceylon.

\section{LV.-Natural History Notes from H.M. Indian Marine} Survey Steamer 'Investigator,' Commander T. H. Heming, R.N.--Series III., No. 1. On Mollusca from the Bay of Bengal and the Arabian Sea. By Edgar A. Suith, I.S.O.

[Continued frum vol. iv. p. 251.]

IN these 'Annals' for 1899, vol. iv. pp. 237-251, diagnoses were given of thirty-five new species from the collection about to be described. The publication of such lists as the following are of importance as regards our knowledge of both geographical and bathymetrical distribution. Many of the species were obtained at Stations 229,232 , and 233, the exact positions of which are as follows :-

Station 229. - Lat. $9^{\circ} 29^{\prime} 34^{\prime \prime}$ N., long. $75^{\circ} 38^{\prime}$ E.: 360 fath.; green mud.

Station 232. - Lat. $7^{\circ} 17^{\prime} 30^{\prime \prime}$ N., long. $76^{\circ} 51^{\prime}$ E.: 430 fath.; grey mud.

Station 233. - Lat. $13^{\circ} 17^{\prime} 15^{\prime \prime}$ N., long. $93^{\circ} 10^{\prime}$ E. : 185 fath.; sand.

Ann. \& Mag. N. Hist. Ser. 7. Vol. xiii. 